\title{
Pectoral-fin glands and delivery apparatus in the catfish genus Brachyrhamdia Myers, 1927 (Siluriformes: Heptapteridae)
}

\author{
Thaís Isabela Carvalho ${ }^{1,2,3}$; Julia Klaczko ${ }^{2,4}$ \& Veronica Slobodian ${ }^{1,5}$ \\ 1 Universidade de Brasília (UNB), Instituto de Ciências Biológicas (ICB), Departamento de Zoologia, \\ Laboratório de Ictiologia Sistemática. Brasília, DF, Brasil. \\ 2 Universidade de Brasília (UNB), Instituto de Ciências Biológicas (ICB), Departamento de Ciências Fisiológicas, \\ Laboratório de Anatomia Comparada de Vertebrados. Brasília, DF, Brasil. \\ ${ }^{3}$ ORCID: http://orcid.org/0000-0002-2238-1647. E-mail: thaiskrvalho@gmail.com \\ ${ }^{4}$ ORCID: http://orcid.org/0000-0002-9215-380X. E-mail: jklaczko@unb.br \\ ${ }^{5}$ ORCID: http://orcid.org/0000-0002-4754-5871. E-mail: vslobodian@unb.br (corresponding author)
}

\begin{abstract}
The Siluriformes, popularly known as catfishes, are probably the vertebrate group with the highest diversity of venomous animals, even though only approximately a hundred venomous catfishes are reported to date. Venomous catfishes might present a delivery system apparatus, formed by an unbranched ray at the leading edge of pectoral and dorsal fins (spine), which can be stiffened and pungent, while venom glands can be present at the surface of such spines and/or the axillary region. This work investigated the presence, morphology and distribution of glands and pectoral-fin delivery apparatus in the heptapterid Brachyrhamdia genus. Pectoral-fin spine external morphology was compared across all valid species in the genus, histological sections of the pectoral-fin spine and axillary regions of $B$. heteropleura and $B$. marthae were produced, and dissections of the pectoral girdle region of the mentioned species were analyzed. The histological sections confirmed the presence of pectoral-fin glands at the surface of the pectoral-fin spine of Brachyrhamdia species, and cellular morphology indicates these glands are probably venomous. Also, we found a piriform gland at the axillary region, whose cell morphology is like the reported for other catfishes. However, we cannot currently confirm or deny axillary gland participation in the venom delivery apparatus. This work constitutes the first report of venom glands in Brachyrhamdia, and the first description of Heptapteridae axillary glands.
\end{abstract}

Keywords. Axillary glands; Comparative anatomy; Histology; Neotropical ichthyology.

\section{INTRODUCTION}

The Siluriformes, popularly known as catfishes, are an extremely diverse fish order, comprised of more than 4,000 valid species (Fricke et al., 2020). Despite the majority being freshwater species, distributed throughout almost all great land masses (except Antarctica, where only fossils have been found, and Australia, where there are marine representatives), two families also present marine species (Ariidae and Plotosidae) (Nelson et al., 2016). The majority of Siluriformes are found in the Neotropical region (Ota et al., 2015), where they constitute $37 \%$ of freshwater fish diversity (Albert et al., 2020). Although venomous representatives have been reported in this order for the past 300 years, recent studies indicate that catfishes possibly outnumber all other venomous vertebrates combined (Wright, 2009; Smith et al., 2016). Therefore, catfish species display a high de- gree of variation in venom delivery apparatus and glands (Wright, 2009, 2015).

Pectoral-fin and axillary glands of catfishes are holocrine glands frequently deemed venomous (hence their common name: 'venom glands') because they have a traumagenic device to purvey their produced substance in the targeted organism (Halstead, 1970). When present, such glands may be found at the bony spine surface, axillary region, or both locations (Wright, 2009). The bony spines of catfishes are derived from an unbranched ray at the leading edge of pectoral and dorsal fins. Pectoral-fin spine morphology varies significantly across the order and, while some species present smooth flexible rays, others show heavily ossified structures, forming proper spines with saw-like projections along anterior and/or posterior edges (Kubicek et al., 2019). Several catfishes use their spines against predators or other potential threats (including humans), causing in- 
jury and venom release (e.g., Haddad \& Martins, 2006; Silva et al., 2010; Aquino et al., 2016; Haddad, 2016). However, the hypothesis that spines and associated glands represent anti-predatory adaptations in catfishes, despite widespread reports in the literature (Birkhead, 1967, 1972; Cameron \& Endean, 1971, 1973; Magalhães et al., 2005; Bosher et al., 2006; Kiehl et al., 2006; Emmett \& Cochran, 2010), is not supported with rigorous tests. Nevertheless, in order to produce a robust hypothesis regarding the adaptive value of such glands, we must first understand their structure and presence across catfish species.

The surface pectoral-fin glands are located adjacent to the epidermis, along the length of the spine. When the spine is driven against the body of a potential predator the integument is torn, resulting in surface gland rupture and venom release (Wright, 2009). In this instance, the presence of denticulations, serrations, or other types of spine ornamentation, potentially increases damage and the surface area of the wound in contact with the venom (Reed, 1907; Birkhead, 1972; Egge \& Simons, 2011). The extent of venom glands in relation to spine serrations varies significantly across catfish species (Halstead, 1988; Wright, 2009; Egge \& Simons, 2011). However, there is little evidence of correlation between the level of spine ornamentation and the magnitude or toxicity of venom glands (Birkhead, 1972; Egge \& Simons, 2011).

Axillary glands, on the other hand, are well-delimited: inside the body wall, near the pectoral girdle, usually lobulated and connected with the surface via a duct opening in the axillary pore (Reed, 1907; Halstead et al., 1953; Wright, 2015), which putatively brings the gland contents to body surface, and is not in any way connected to the lateral line system. Although they have been described for several catfish families, no comprehensive survey has been performed to document their distribution throughout Siluriformes (Perrière \& GouldeyPerrière, 2003; Wright, 2015). Despite the contents of catfish axillary glands being sometimes referred to as part of the venom delivery apparatus (e.g., Reed, 1907; Halstead et al., 1953; Birkhead, 1967; Cameron \& Endean, 1971; Perrière \& Gouldey-Perrière, 2003), literature regarding the production of venomous substances by these glands is inconclusive. The earliest report of axillary glands in catfishes was by Günther (1880: 192) who stated that Siluroids have an axillary sac with an opening in the region near the pectoral-fin base. However, this report did not discuss axillary sac contents. The first study to systematically address axillary gland structure and composition in catfishes was by Reed (1907), in which he described this gland in Noturus Rafinesque, 1818 species. In this same work, Reed proposed that N. gyrinus (Mitchill, 1817) (referred to in his work as Schilbeodes gyrinus) gland secretions should be deemed venomous as accidents with pectoral-fin spines provoke the sensation of pain and swelling, and that axillary gland products ought to reach the accident sites when anointing the spines via the axillary pore (Reed, 1907). However, Cameron \& Endean (1971) objected to this hypothesis, arguing that the axillary gland secretion does not coat the pectoral spine. Furthermore, Al-Hassan et al. (1987) found the skin secretion of Arius Valenciennes, 1840 species to be more toxic than the "venomous" secretion of the axillary gland. Therefore, despite being commonly referred to as venomous glands, the role(s) of axillary gland secretions remain disputed (Whitear et al., 1991; Wright, 2015).

Nevertheless, what is commonly referred to as the catfish venom gland presents binucleated cells enclosed within an integumentary sheath composed of epithelial cells (Reed, 1907; Halstead et al., 1953; Halstead, 1988; Wright, 2015). Pectoral-fin venom gland cells are distributed at the surface of catfish pectoral-spines, visualized as large, polygonal cells with prominent nucleoli and a granular cytoplasm. Axillary gland cells, on the other hand, present vesicles containing a viscous, proteinaceous secretion in intact cells, and also disintegrating cells that suffered autolysis, releasing the secretion (Vernick \& Chapman, 1968; Whitear et al., 1991; Zaccone et al., 2001; Kiehl et al., 2006). Several catfish species also present epidermal club cells along their bodies that secrete toxic products including crinotoxins, protein secretions released into the water when cells are ruptured to repel predators (Halstead, 1970; Cameron \& Endean, 1973; Perrière \& Gouldey-Perrière, 2003). However, catfish venom gland cells have immunoreactive, ultrastructural and histochemical differences that enable their discrimination from epidermis club cells (Zaccone et al., 1990; Whitear et al., 1991).

Catfish venoms have hemolytic and dermonecrotic properties, causing severe pain, muscle spasm, ischemia and other distresses (Church \& Hodgson, 2002; Haddad \& Martins, 2006). However, despite anecdotal knowledge regarding the presence of venom in several catfishes (Halstead, 1988), studies regarding chemical structure, enzymology, toxicology, and distribution among taxa remain sparse (Birkhead, 1972; Gwee et al., 1994; Hahn \& O'Connor, 2000; Church \& Hodgson, 2002; Magalhães et al., 2005; Smith \& Wheeler, 2006; Jawad, 2018). Furthermore, while estimates indicate that almost half the number of catfish species are presumably venomous and that catfishes may account for up to $58 \%$ of the diversity of venomous fishes (Smith et al., 2016), only about a hundred venomous catfish species have been reported to date, what corresponds to approximately $7 \%$ of the minimum number of venomous species estimated for this order (Wright, 2009, 2015; Smith et al., 2016).

Among the Siluriformes, the Heptapteridae Gill, 1861 are especially interesting for studies regarding the anatomy/evolution of venom glands and delivery apparatus, given the variation in pectoral-fin spines. A number of its genera present stiffened, pungent, ornamented spines (Brachyrhamdia Myers, 1927; Pimelodella Eigenmann \& Eigenmann, 1888; Rhamdia Bleeker, 1858), while others present flexible, brittle, smooth spines (Imparfinis Eigenmann \& Norris, 1900; Mastiglanis Bockmann, 1994). Despite venom glands usually being associated with a venom delivery system through pungent spines, at least one Heptapteridae species with brittle spines, Imparfinis lineatus (Bussing, 1970), is known to possess venom glands (Wright, 2009). Indeed, current estimates of ven- 
omous Heptapteridae range from 91 to 160 of 227 species (Wright, 2015), which is likely an underestimate. Furthermore, axillary glands have never been reported for members of this family.

To gain a better understanding of venom gland morphology and delivery apparatus in Heptapteridae, we investigated the presence, morphology, and distribution of glands associated with the pectoral fin (both surface glands of the pectoral-fin spine and axillary glands) in Brachyrhamdia, a Neotropical genus with six valid species distributed in the Amazonian and Orinoco basins (Slobodian \& Bockmann, 2013). These species are known for their small size (not exceeding $8 \mathrm{~cm}$ ), remarkable color patterns and are apparently mimetic with species of Corydoras La Cepède, 1803 (Slobodian \& Bockmann, 2013). Despite being known by aquarists, they remain rare in the aquarium trade and scientific collections, probably due to difficulties associated with finding them in nature. The genus Brachyrhamdia retains several plesiomorphic characters found in the Heptapteridae family (such as the presence of a pungent spine, long occipital process, and free orbital rim; Bockmann \& Miquelarena, 2008), but remains without a published phylogenetic diagnosis, and is considered as valid a priori. All Brachyrhamdia species present stiffened pectoral-fin spines, with a series of ornamentations along anterior and posterior margins. To our knowledge, this is the first report of surface venom glands and axillary glands in these species, despite previous accounts of notably painful injuries caused by their spines (Axelrod, 1987).

\section{MATERIAL AND METHODS}

\section{Materials and gross anatomical descriptions}

The external morphology of pectoral-fin spines was analyzed for all valid Brachyrhamdia species (see Examined Material). Adult specimens of $B$. marthae Sands \& Black, 1985 and B. heteropleura (Eigenmann, 1912) were thoroughly analyzed following macroscopic and histological preparation. Macroscopic pectoral-fin spine analyses were conducted in alcohol-preserved and cleared and stained material according to Taylor \& Van Dyke (1985). The axillary gland gross anatomy was described after dissection of the ventral pectoral region of alcohol-preserved specimens under a stereomicroscope, after removal of the hypaxial musculature near the pectoral girdle. Histological processing was conducted for other specimens of the selected species after prior dissection of pectoral fins, girdle and the adjacent region under a stereomicroscope.

All analyzed material belonged to scientific collections and was preserved in $70 \%$ ethanol, except for cleared and stained specimens, which were preserved in glycerin. Institutional abbreviations follow Sabaj (2016). Notations cited throughout the text include "c\&s" for cleared and stained specimens, "hist" for histological prepared specimens, " $x y$ " for radiographed specimens, and "SL" for Standard Length. Measurements of body parts and structures are presented as percentages of Standard length. Gross anatomy of pectoral-fin spine nomenclature follows Slobodian \& Bockmann (2013) and Vanscoy et al. (2015), with pertinent modifications from Kubicek et al. (2019).

\section{Histological procedures}

In order to determine the presence, distribution and cell morphology of glands, pectoral-fin spines and adjacent regions were decalcified in 5\% EDTA. Segments were subsequently subjected to dehydration, xylol clearing, paraffin infiltration and embedding following Behmer et al. (1976). Semi-serial 5- $\mu$ m sections were obtained from each sample, mounted on glass slides and stained with hematoxylin and eosin.

Spines and pectoral region sections were examined for the presence of glands using a Leica DM 2000 microscope. Slides were scanned at high resolution using an EVOS FL Auto microscope. Morphological confirmation of gland presence was achieved by comparisons with the available literature on such glands and their cellular anatomy in catfishes (Halstead et al., 1953; Birkhead, 1972; Cameron \& Endean, 1973; Halstead, 1978; Whitear et al., 1991; Wright, 2009, 2012, 2015).

Images were edited using the Adobe Photoshop CC 2019, Adobe Illustrator CC 2020 and Inkscape softwares. Cell measurements were taken using the ImageJ 1.53 e software.

\section{RESULTS}

All examined Brachyrhamdia specimens presented a single slit-like axillary pore on each side, dorsal to pectoral-fin base, adjacent to the posterior process of cleithum. Microdissection of B. marthae and B. heteropleura specimens thoracic regions revealed a piriform axillary gland. Axillary glands, pectoral-fin spines and their surface glands are described in the following sections.

\section{Axillary gland morphology}

Brachyrhamdia marthae and B. heteropleura axillary glands are piriform, anteroposterior axis the longest, and broader at anterior border. They are positioned medially to the posterior process of cleithrum and posterior to the abductor superficialis muscle, surrounded by loose connective and adipose tissues (Fig. 1). The axillary gland is divided into many lobules and is notably smaller in $B$. heteropleura (longest diameter of $1.30 \mathrm{~mm}, 3.9 \% \mathrm{SL}$ ) than in B. marthae (longest diameter of $2.94 \mathrm{~mm}, 9.3 \% \mathrm{SL}$ ), despite both dissected specimens being of similar size (33.4 $\mathrm{mm} \mathrm{SL}$ and $31.4 \mathrm{~mm} \mathrm{SL}$, respectively).

Longitudinal oblique sections of the Brachyrhamdia heteropleura pectoral girdle region revealed typical holocrine gland cells wrapped in a thin capsule of connective tissue (Fig. 2). Delimited internal partitions and support 

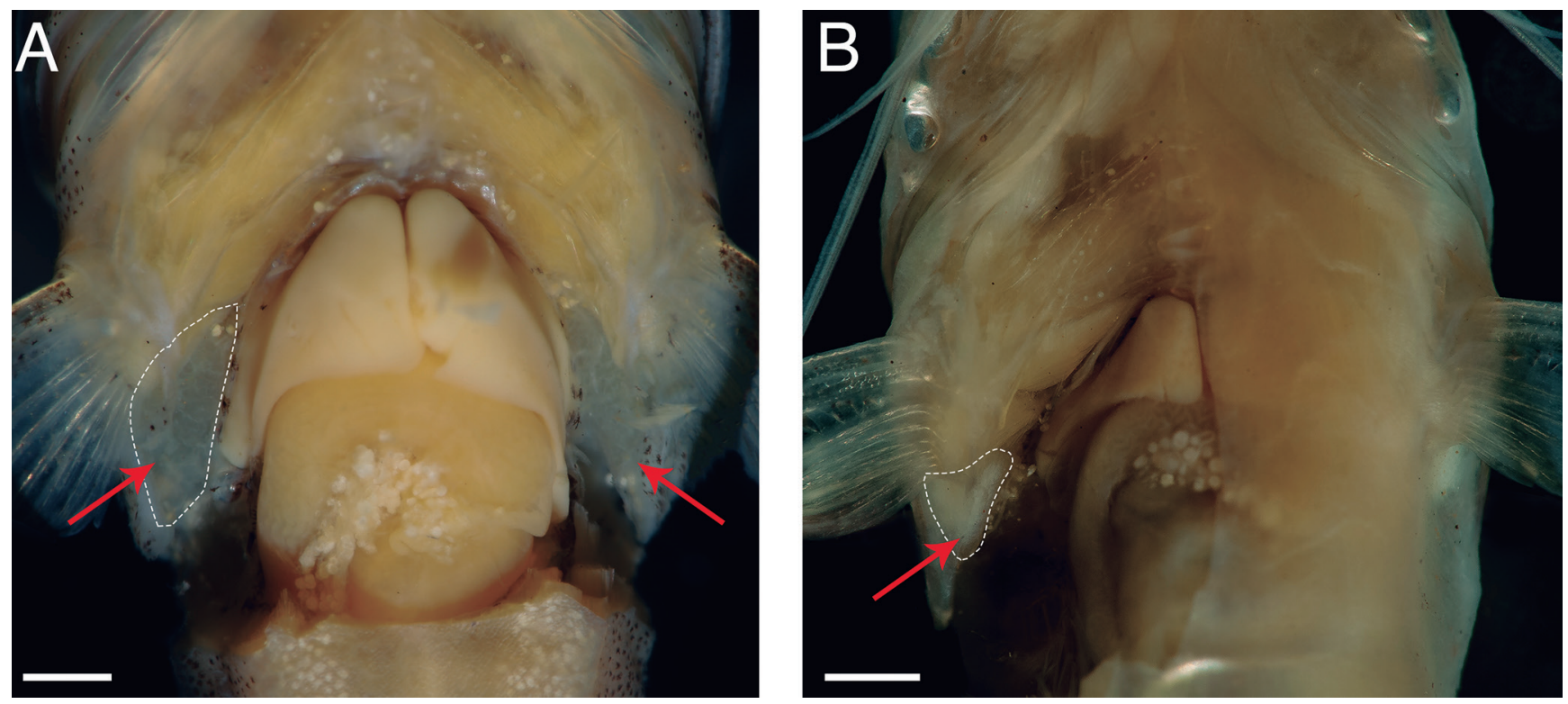

Figure 1: Ventral view of the pectoral region of Brachyrhamdia species, exposed in situ axillary glands after the removal of skin, hypaxial musculature and loose connective tissue and adipose tissue. (A) Brachyrhamdia marthae, LIRP 10040, $31.4 \mathrm{~mm}$ SL. Both left and right axillary glands (arrow) are exposed, right gland limits highlighted by white dashed line. (B) Brachyrhamdia heteropleura, LIRP 7419, $33.4 \mathrm{~mm}$ SL. Right axillary gland is exposed (arrow), with its limits highlighted by white dashed line, and portion of left axillary gland can be seen near pectoral-fin base by transparency. Scale bar: $1 \mathrm{~mm}$.

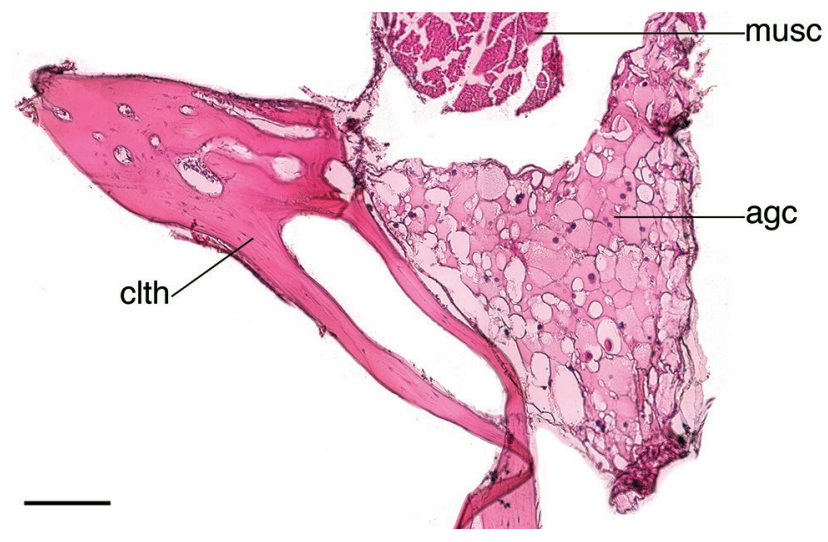

Figure 2. Longitudinal oblique section of $B$. heteropleura left pectoral fin girdle, LIRP 7419, $30.9 \mathrm{~mm} \mathrm{SL}$, indicating gland cells wrapped by connective tissue. Abbreviations: agc = axillary gland cells (including binucleated cells), musc $=$ musculature, clth $=$ cleithrum. Scale bar: $0.5 \mathrm{~mm}$.

cells were not discriminated. Axillary gland cells are polygonal, with marked nucleolus and pale pink cytoplasm, measuring between 22-60 $\mu \mathrm{m}$. Gland cells are filled with light-colored secretory vesicles, several cells are ruptured, and we can observe numerous binucleated cells (Fig. 2).

\section{Pectoral-fin spine and surface glands}

The Brachyrhamdia species examined have the first pectoral-fin ray unbranched, stiffened, with most of its length forming a bony spine with a short distal tip which is flexible and distinctly segmented, corresponding to the spurious ray formed by an actinotrichia bundle. Brachyrhamdia spines present a bony lamina extending from the anterior midline of the spine, and retrorse extensions (serrae) developing along the posterior edge.
Brachyrhamdia marthae differs from all Brachyrhamdia species, with the exception of $B$. meesi, due to the absence of anterior margin denticulations on the pectoral-fin spine, presenting an anterior ridge along most of its length, together with smooth serrae at the distalmost portion of the spine. Following Kubicek et al. (2019), the distal anterior serrae of the spine probably corresponds to the point of initial fusion between the hemitrichia of each segment. The Brachyrhamdia marthae spine also presents 7 or 8 antrorse (towards distal portion of spine) to straight serrae along roughly half the length of the basal posterior margin, some of which present a bifid apex (Figs. $3 A_{1}, 3 A_{2}$ ). On the other hand, the anterior margin of the pectoral-fin spine in Brachyrhamdia heteropleura presents several minute denticulations, straight to antrorse, along its basal half, with smooth serrae along its distal third. The denticuli of the spine anterior margin, when present, might be resulted of bone remodeling or addition to the existing bony lamina (Kubicek et al., 2019). The posterior margin of the pectoral-fin spine usually presents 7 or 8 retrorse (towards the base of spine) serrae from the region just beyond base of the spine to, or slightly shorter than, half of the spine length (Figs. 3B $\mathrm{B}_{1}, 3 \mathrm{~B}_{2}$ ).

Transversal sections of Brachyrhamdia marthae and $B$. heteropleura pectoral-fin spines show gland cells between the spine bone and epidermis (Fig. 4). The cells observed were identified as venom glands due to similarities with catfish venom glands described in the literature (Wright, 2009; Egge \& Simons, 2011). They have an overall polygonal shape, measuring between 11-37 $\mu \mathrm{m}$. Furthermore, they are adjacent to the bone, internal to what appear to be epidermal club cells (Fig. 4B $\mathrm{B}_{2}$ ) and present a granular cytoplasm (more evident in Fig. $4 A_{2}$ ). In both $B$. marthae and $B$. heteropleura, the gland cells were found to be concentrated at the posterior margin 


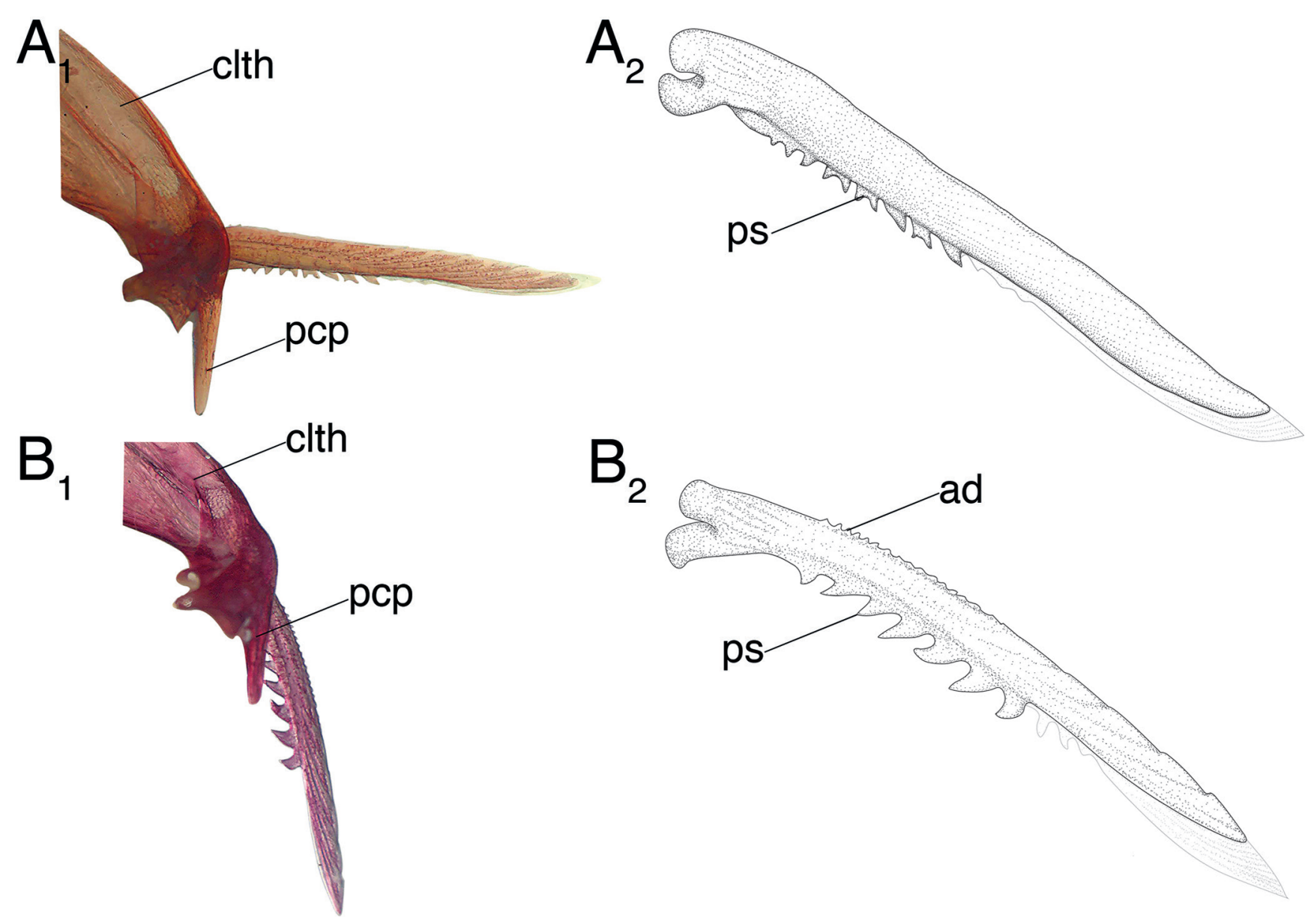

Figure 3. $\left(A_{1}\right)$ Dorsal view of Brachyrhamdia marthae right pectoral-fin spine and girdle, USNM 305641, total spine length $5.8 \mathrm{~mm} ;\left(\mathrm{A}_{2}\right)$ Illustration of $B$. marthae right pectoral-fin spine in dorsal view. Black indicates the ossified portion of spine, while gray portion indicates the unossified spurious ray; $\left(B_{1}\right)$ Dorsal view of B. heteropleura right pectoral-fin spine and girdle, USNM 226105 , total spine length $4.6 \mathrm{~mm} ;\left(B_{2}\right)$ Illustration of $B$. heteropleura right pectoral-fin spine in dorsal view. Black indicates the ossified portion of the spine, while the gray portion indicates the unossified spurious ray (completed according to left pectoral-fin spine). The proximal portion of spine cannot be observed when the spine is articulated, therefore illustrations of such portion were produced according to direct observation. Abbreviations: $\mathrm{ad}=$ anterior denticulation, $\mathrm{clth}=$ cleithrum, $\mathrm{pcp}=$ posterior cleithrum process, $\mathrm{ps}=$ posterior serration.

of the spine, near the posterior pectoral-fin spine serrae (Fig. 4). No muscle tissue or ducts were associated with the venom spine or gland.

\section{DISCUSSION}

Despite the widespread occurrence of axillary glands in catfishes, to our knowledge, this is the first study describing them in members of Heptapteridae. The axillary gland in the Brachyrhamdia species examined is located in the same position as those described for other Siluriformes (Reed, 1907; Halstead et al., 1953; Halstead \& Smith, 1954; Cameron \& Endean, 1971; Whitear et al., 1991; Greven et al., 2006), thereby allowing identification through dissection and histology. Axillary glands in Brachyrhamdia appear to be typical holocrine secretion glands. Histological sections of $B$. heteropleura allowed us to compare axillary gland cell morphology with those previously reported in the literature. Unlike Corydoras aeneus (Gill, 1858) (Callichthyidae) (Greven et al., 2006) and Noturus spp. (Ictaluridae) (Reed, 1907), the B. heteropleu$r a$ axillary gland did not present a true lumen, since there was no definite boundary between the secretion and disintegrating cells. The absence of a true lumen in the axillary gland was also reported for Cnidoglanis macrocephalus (Valenciennes, 1840) (Plotosidae) and Ameiurus nebulosus (Lesueur, 1819) (Ictaluridae), that also do not possess the lobulation partitions of connective tissue extending to the center of the gland (Cameron \& Endean, 1971; Whitear et al., 1991). The cellular morphology of $B$. heteropleura axillary glands, pertaining to gland cell maturation, is also similar to $C$. macrocephalus, in that immature secretory cells are binucleated and possess haematoxylinophilic cytoplasm. Moreover, during maturation, the cytoplasm becomes eosinophilic, nuclei disappear and the cell is released from its contact with adjacent cells, eventually rupturing and releasing the secretory product (Cameron \& Endean, 1971). Nucleated (and even binucleated) cells with darker cytoplasm (immature secretory cells) and larger cells with pale pink cytoplasm and no nuclei (mature secretory cells) can be observed in Fig. 2.

According to previous catfish axillary gland descriptions, concerning their cell morphology and coloration (Al-Hassan et al., 1987; Whitear et al., 1991; Greven et al., 

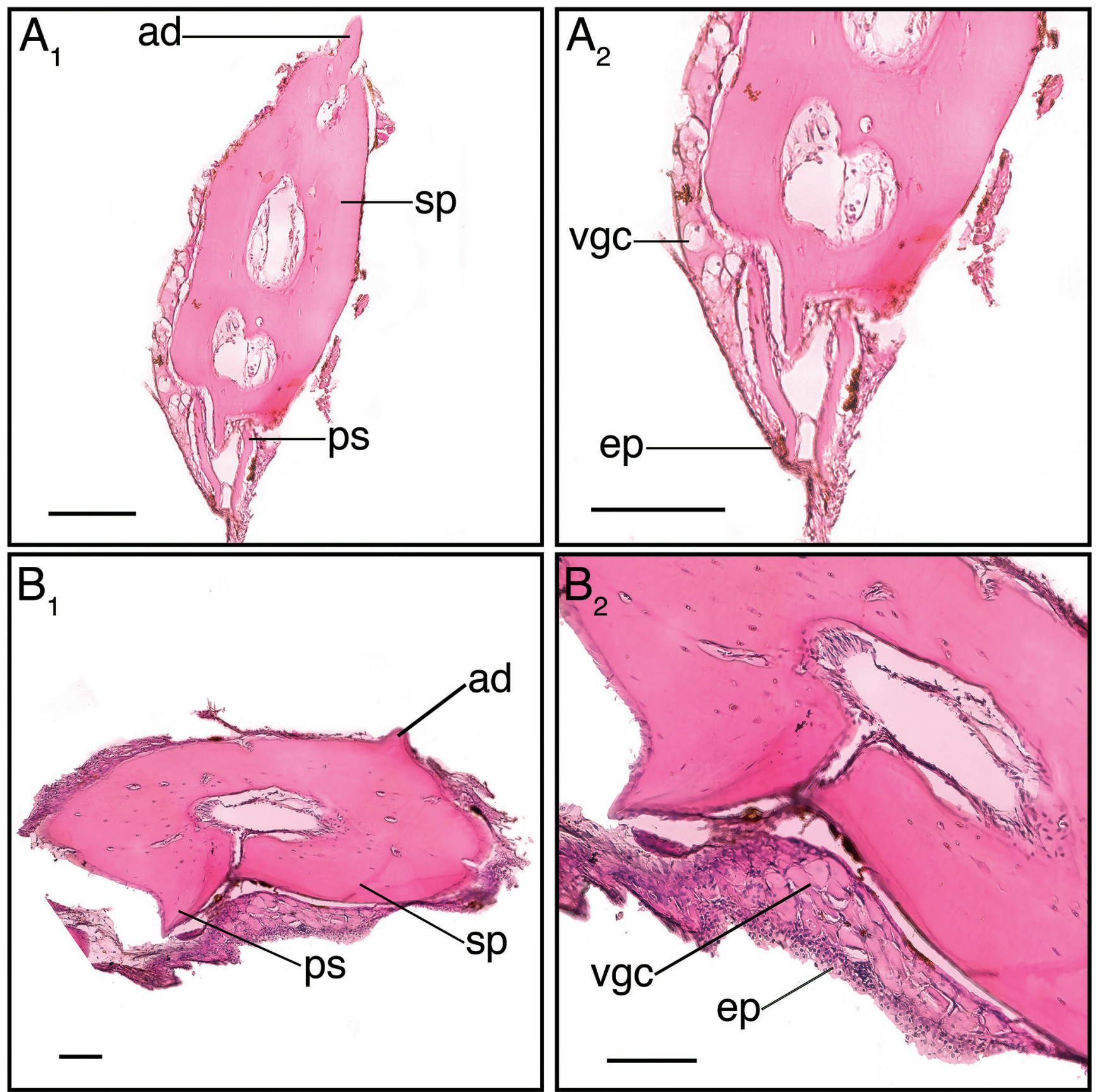

Figure 4: Histological preparations of the right pectoral-fin spine of Brachyrhamdia species, indicating gland cells between bony spine and epidermis. (A) B. marthae, LIRP 10040, $23.9 \mathrm{~mm} \mathrm{SL}$, transversal section: $\left(A_{1}\right)$ General view of spine $\left(A_{2}\right)$ Detail of posterior edge of spine. (B) B. heteropleura, LIRP 7419, $30.9 \mathrm{~mm} \mathrm{SL}$, oblique transversal section: $\left(B_{1}\right)$ General view of spine; $\left(B_{2}\right)$ Detail of posterior edge of spine. Abbreviations: $a d=$ anterior denticulation, ep $=$ epidermis, $\mathrm{ps}=$ posterior serration, $\mathrm{sp}=$ pectoral-fin spine, $\mathrm{vgc}=$ superficial pectoral-fin spine venom gland cells. Epidermal cells indicated in B. heteropleura morphologically resemble club cells. Scale bar: $0.05 \mathrm{~mm}$.

2006; Kiehl et al., 2006), we believe the contents secreted by the $B$. heteropleura axillary gland might be significantly proteinaceous in nature. Additionally, the absence of support cells could be an artifact from the decalcification procedure, since this type of cell is probably common to all venom glands (Halstead, 1970). As our specimens were collection materials, formalin-fixed and preserved in alcohol for many years, their histological preparation was troublesome. Therefore, immunohistochemical studies were not possible to better assess the nature of axillary gland cells and their products. However, future immunohistochemical, pharmacological and molecular investigations can properly identify fine cellular structure and secretion properties.

The function of catfish axillary gland secretions remains unknown, as does the natural secretory mechanism, although there are reports of secretions being released as a burst in the event of pressure application to the axillary region (Cameron \& Endean, 1971; Greven et al., 2006). A number of authors suggested axillary gland secretions might play a pheromonal, bactericidal or ichthyotoxic role, especially under stressful conditions (Cameron \& Endean, 1971; Greven et al., 2006; Kiehl et al., 2006). However, we do not currently understand to what 
extent axillary gland secretions contribute to antimicrobial activity, or to what degree they contribute to the pain and other effects people experience when stung by the pectoral-fin spine. Therefore, we cannot currently confirm or deny participation of the axillary gland in the venom delivery apparatus, or fully understand the secretory mechanism. Due to the uncertainties regarding the role of axillary gland secretions, "venom delivery apparatus" (or just "venom apparatus") is the term commonly used to refer to the dorsal and pectoral spines and their associated glands, not including the axillary gland. Under this nomenclature, we will now further discuss the pectoral-fin venom apparatus.

The venom apparatus was described for several catfish species (see Perrière \& Gouldey-Perrière, 2003 for a revision), but the most comprehensive pectoral-fin venom gland study published to date is that of Wright (2009). This work examined 159 catfish species, described the presence of venom glands in more than a hundred species from 20 catfish families, and estimated 1,234-1,625 catfish species could be venomous, a condition that evolved several times in Siluriformes.

Catfish venom glands are typically composed of glandular cells associated with an unbranched pectoral-fin ray, that can be rigid (forming a bony spine) or brittle, and possess serrations in both anterior and/or posterior margins. Of the eleven species without bony spines examined by Wright (2009), two presented glandular cells (Nematogenys inermis (Guichenot, 1848) and Imparfinis lineatus), demonstrating there is not a direct correlation between bony spines and glands. However, without the delivery apparatus provided by the spine, the role of such glands is yet to be investigated.

The tissue found in the surface of Brachyrhamdia spines is similar to the venom gland cells reported for other catfishes: along the length of the spine, the venom cells are in direct contact with bone and subjacent to the epidermis (Wright, 2009; Egge \& Simons, 2011). Venom gland cells are large, polygonal and possess a highly granulous cytoplasm (presumably due to a high concentration of venomous peptides) that tend to be more eosinophilic than epidermal club cells (Egge \& Simons, 2011; Wright, 2015). The configuration of venom cells found in the Brachyrhamdia species examined is somewhat similar to that reported by Wright (2009: fig. 3A) for Pimelodella mucosa Eigenmann \& Ward, 1907, another heptapterid species. However, while gland cells were found around the spine circumference in $P$. $m u$ cosa, Brachyrhamdia species presented glandular cells concentrated at the posterior margin of spine, near the posterior serrae (Fig. 4). In B. heteropleura, we could also observe epidermal cells adjacent to the gland cells, that may correspond to club cells (Figs. $4 \mathrm{~B}_{1}, 4 \mathrm{~B}_{2}$ ).

Among Heptapteridae, Brachyrhamdia is one of the genera with ossified, pungent, pectoral-fin spines, a condition shared with other genera such as: Brachyglanis Eigenmann, 1912; Gladioglanis Ferraris \& Mago-Leccia, 1989; Goeldiella Eigenmann \& Norris, 1900; Leptorhamdia Eigenmann, 1918; Myoglanis Eigenmann, 1912; Pimelodella; Rhamdella Eigenmann \& Eigenmann,
1888; and Rhamdia (Bockmann \& Slobodian, 2017). Previous analyses of pectoral-fin spine glands among Heptapteridae genera demonstrated a single, large, circumferential gland in Myoglanis sp. and Pimelodella mucosa; while paired anterior and posterior glands were found in Rhamdia guatemalensis (Günther, 1864) (Wright, 2009). Glandular cells restricted to the posterior margin of the spine, as observed here in Brachyrhamdia, have only been reported in Imparfinis lineatus (Wright, 2009), which presents a brittle pectoral-fin spine and is not proximately related to the Brachyrhamdia genera (Bockmann \& Miquelarena, 2008; Silva et al., 2021). However, our histological procedures involved collection materials, resulting in the rupture of tissues surrounding the pectoral-fin spine. Therefore, in order to confirm the uniqueness of pectoral-fin venom apparatus in Brachyrhamdia in relation to other Heptapteridae (a rigid and pungent pectoral-fin spine, with venom gland cells restricted to its posterior margin), undamaged histological sections of other specimens are required. Unfortunately, Brachyrhamdia specimens are very rare in scientific collections and, in spite of being present in the aquarium trade, they are not frequently found. That said, the present findings regarding Brachyrhamdia venom apparatus are promising, and further investigation might prove useful in the taxonomic delimitation of Heptapteridae species.

The phylogenetic relationships of Heptapteridae genera are not completely settled and the validity of Brachyrhamdia has been questioned in the literature due to similarities shared with the Pimelodella and Rhamdia genera (Bockmann \& Miquelarena, 2008; Slobodian \& Bockmann, 2013). Indeed, Brachyrhamdia has been repeatedly proposed as a junior-synonym of Pimelodella (Schultz, 1944; Innes \& Myers, 1950; Sands, 1985; Lundberg \& McDade, 1986; Axelrod, 1987; Bockmann, 1998; Guazzelli, 2003), but remains as valid a priori, since its species probably encompasses a monophyletic group (Bockmann \& Miquelarena, 2008) and Pimelodella is probably a non-monophyletic genus (Silva et al., 2021). An unpublished master's degree dissertation (Slobodian, 2013) recovered Brachyrhamdia as a valid genus, differentiated from other Heptapteridae, with B. marthae more closely related to $B$. meesi Sands \& Black, 1985 than to all other Brachyrhamdia, and B. heteropleura more closely related to an undescribed species. In this sense, the sampling herein of Brachyrhamdia species might enable the extrapolation of venom gland characteristics for the entire genera. If future studies of Brachyrhamdia venom apparatus recover similar results, the characteristics regarding venom gland morphology can be promising, at least, in Brachyrhamdia taxonomic delimitation compared to other Heptapteridae.

Another interesting fact about Brachyrhamdia is that some of its species occur syntopically with species of the callichthyid genus Corydoras, with which they share a striking resemblance in overall body shape and color pattern, indicating a case of mimicry between species of both genera (Innes \& Myers, 1950; Sands, 1985; Lundberg \& McDade, 1986; Axelrod, 1987). Despite Corydoras species being covered by a body armor, both Brachyrhamdia 
and Corydoras species present pungent pectoral- and dorsal-fin spines, that lock in a defensive tripod when under stress (Slobodian \& Bockmann, 2013). Since both species have anti-predation attributes, Slobodian \& Bockmann (2013) suggested their association would set a mutual benefit, fitting the category of Müllerian mimicry.

Previous studies indicated the presence of surface glands in the pectoral-fin spine of Corydoras aeneus, C. sterbai Knaack, 1962 and C. paleatus (Jenyns, 1842), and prominent axillary glands in $C$. aeneus and $C$. sterbai (Greven et al., 2006; Kiehl et al., 2006; Wright, 2009). Analyses of gland extracts of the aforementioned species indicated their toxic nature (Greven et al., 2006; Kiehl et al., 2006), with loss of coloration (a symptom of envenomation) when C. paleatus gland product was artificially injected into a largemouth bass (Wright, 2009). Therefore, pharmacological investigation of Brachyrhamdia venom gland secretions might shed some light on the type of mimicry between Brachyrhamdia and Corydoras species. If peptide toxins of Corydoras are found to be more toxic than Brachyrhamdia secretions, Batesian mimicry would be a better fit for the association between both genera, since the mimic (Brachyrhamdia) would not have the same attributes that make the model (Corydoras) unprofitable (Remington, 1963). Nevertheless, the type of mimicry association between Brachyrhamdia and Corydoras species warrants further investigation.

While venomous fishes have received relatively less research attention than other groups of venomous organisms, catfishes in particular have suffered from a lack of focused studies (Wright, 2015). The results presented here add information to a still poorly studied field, and demonstrate how characters derived from venom glands and delivery system apparatus can be useful in describing taxonomic diversity, solving phylogenetic relationships, or understanding apparatus evolution on a finer scale (Wright, 2009; Egge \& Simons, 2011).

\section{EXAMINED MATERIAL}

Brachyrhamdia heteropleura: AMNH 52410, 35, 2 c\&s, 30.8-43.3 mm SL; AMNH 54970, 1, $33.1 \mathrm{~mm} \mathrm{SL;}$ ANSP 179737, 20, 25.0-39.6 mm SL; INPA 7906, 2, 35.5-39.6 mm SL; LIRP 7415, 3, 33.6-37.6 mm SL; LIRP 7419, 6, 1 hist, 30.5-35.3 mm SL; USNM 226105, 13, 2 c\&s, 29.3-36 mm SL.

Brachyrhamdia imitator: CAS 54359, 1, $69.4 \mathrm{~mm} \mathrm{SL}$, holotype; AMNH 58322, 3, 36.1-76.7 mm SL; ANSP 135585, 337, 26-54 mm SL; ANSP 135601, 20, 30-38.5 mm SL; MCP 15132, 8, 1 c\&s, 34.7-39.9 mm SL; MZUSP 84669, 4, 33.5-36.2 $\mathrm{mm} \mathrm{SL}$.

Brachyrhamdia marthae: RMNH 29424, 1, 76 mm SL, holotype; AMNH 225416, 1, 27.2 mm SL; AMNH 77576, 4, 22.6-26.8 mm SL; LIRP 10040, 30, 1 hist, 23.6-32.9 mm SL; MCP 15555, 3, 26.5-28.0 mm SL; MZUSP 30771, 3, 32.8-45.1 mm SL; MZUSP 118425, 12, 27.4-31.3 mm SL;
MZUSP 118428, 11, 27.1-36.5 mm SL; UF 128932, 1, $24 \mathrm{~mm} \mathrm{SL;} \mathrm{UF} \mathrm{128977,} \mathrm{5,} \mathrm{23.3-33} \mathrm{mm} \mathrm{SL;} \mathrm{UF} \mathrm{129036,}$ 2, 29-32.5 mm SL; UFRO-I 3277, 1, $25.6 \mathrm{~mm} \mathrm{SL;}$ USNM 305631, 15, 2 c\&s, 26.5-33.2 mm SL; USNM 305864, 40,2 c\&s, 34.1-42.2 mm SL.

Brachyrhamdia meesi: RMNH 29425, 1, $56.5 \mathrm{~mm} \mathrm{SL;}$ INPA 8047, 1, 1 c\&s, 43.37 mm SL; MZUSP 87209, 1, xy, 57.7 mm SL; MZUSP 118426, 11, 36.9-48.2 mm SL; MZUSP 118427, 1, $35.0 \mathrm{~mm}$ SL; UFRJ 0397, 2 c\&s, 42.8-45.2 $\mathrm{mm} \mathrm{SL}$.

Brachyrhamdia rambarrani: MZUSP 37693, 1, 55 mm SL, holotype; USNM 288460, 1, $53 \mathrm{~mm} \mathrm{SL}$, paratype; INPA 9188, 5, 1 c\&s, 47.3-59.4 mm SL.

Brachyrhamdia thayeria: INPA 39534, $50.7 \mathrm{~mm} \mathrm{SL}$, holotype; ANSP 194110, 1, $35.9 \mathrm{~mm} \mathrm{SL}$, paratype; INPA 25306, 2, 37.9-41.0 mm SL, paratypes; INPA 25740, 1, $31.3 \mathrm{~mm} \mathrm{SL}$, paratype; INPA 25741, 2, 36.8-37.1 mm SL, paratypes; LIRP 10237, 2, 44.5-55.2 mm SL, 1 c\&s, paratypes; MZUSP 114011, 1, $34.1 \mathrm{~mm} \mathrm{SL}$, paratype.

\section{ACKNOWLEDGMENTS}

We especially thank Dr. Flávio A. Bockmann (LIRP/ USP) for lending the histological Brachyrhamdia specimens. We also thank Dr. José Roberto Pujol Luz, M.Sc Alexandre Ariel Souza (ZOO/UnB), Dr. Monica Garcia (GEM/UnB), M.Sc. Anderson De-Lima, Luisa Souza (CFS/ UnB) and Dr. Luiz Peixoto (MZ/USP) for methodological and technical support. Finally, we wish to thank Rafael Maior and Michael D. Taylor for English revision and thoughtful insights. The authors of this work were supported by Conselho Nacional de Desenvolvimento Científico e Tecnológico (PROTAX/156515/2010-5) (VS); DPI/DIRPE UnB Edital 03/2020 and 02/2021 (VS); Ministry of Education, Tutorial Education Program (PET) (TIC).

\section{AUTHORS' CONTRIBUITIONS}

T.I.C.: Conceptualization, Data curation, Formal Analysis, Investigation, Methodology, Visualization, Writing - original draft. J.K., V.S.: Conceptualization, Data curation, Formal Analysis, Funding acquisition, Investigation, Methodology, Project administration, Resources, Supervision, Visualization, Writing - original draft, Writing - review \& editing. All the authors actively participated in the discussion of the results, they reviewed and approved the final version of the paper. Authors declare that there is no conflict of interest related to this paper.

Funding/Support Agencies: VS: Conselho Nacional de Desenvolvimento Científico e Tecnológico; Grant number: PROTAX/156515/2010-5; DPI/DIRPE UnB Edital 03/2020 and 02/2021; TIC: Ministry of Education, Tutorial Education Program (PET). 


\section{REFERENCES}

Albert, J.S.; Tagliacollo, V.A. \& Dagosta, F. 2020. Diversification of Neotropical freshwater fishes. Annual Review of Ecology, Evolution, and Systematics, 51: 27-53. DOI

Al-Hassan, J.M.; Thomson, M.; Ali, M. \& Criddle, R.C. 1987. Toxic and pharmacologically active secretions from the Arabian Gulf catfish (Arius thalassinus, Ruppell). Journal of Toxicology: Toxin Reviews, 6: 1-43.

Aquino, G.N.D.; Souza, C.C.; Haddad-Jr., V. \& Sabino, J. 2016. Injuries caused by the venomous catfish pintado and cachara (Pseudoplatystoma genus) in fishermen of the Pantanal region in Brazil. Anais da Academia Brasileira de Ciências, 88(3): 1531-1537. D0I

Axelrod, H.R. 1987. Two new species of catfishes (Siluriformes, Callichthyidae and Pimelodidae) from the Rio Unini, Amazonas, Brazil. Tropical Fish Hobbyist, 35: 22-25.

Behmer, A.; Tolosa, E.M.C. \& Neto, A.G.F. 1976. Manual de técnicas para histologia normal e patológica. São Paulo, EDART/EDUSP.

Birkhead, W.S. 1967. The comparative toxicity of stings of the ictalurid catfish genera Ictalurus and Schilbeodes. Comparative Biochemistry and Physiology, 22(1): 101-111.

Birkhead, W.S. 1972. Toxicity of stings of ariid and ictalurid catfishes. Copeia, 1972(4): 790-807. DOl

Bockmann, F.A. 1998. Análise filogenética da família Heptapteridae (Teleostei, Ostariophysi, Siluriformes) e redefinição de seus gêneros. (Doctoral thesis) Universidade de São Paulo.

Bockmann, F.A. \& Miquelarena, A.M. 2008. Anatomy and phylogenetic relationships of a new catfish species from northeastern Argentina with comments on the phylogenetic relationships of the genus Rhamdella Eigenmann and Eigenmann 1888 (Siluriformes, Heptapteridae). Zootaxa, 1780: 1-54. DOI

Bockmann, F.A. \& Slobodian, V. 2017. Family Heptapteridae (three-barbeled catfishes). In: Van Der Sleen, P. \& Albert, J.S. (Eds.). Field Guide to the Fishes of the Amazon, Orinoco and Guianas 1. New Jersey, Princeton University Press. p. 233-252.

Bosher, B.T.; Newton, S.H. \& Fine, M.L. 2006. The spines of the channel catfish, Ictalurus punctatus, as an anti-predator adaptation: an experimental study. Ethology, 112: 188-195.

Cameron, A.M. \& Endean, R. 1971. The axillary glands of the plotosid catfish Cnidoglanis macrocephalus. Toxicon, 9(4): 345-352. DOI

Cameron, A.M. \& Endean, R. 1973. Epidermal secretions and the evolution of venom glands in fishes. Toxicon, 11: 401-410. DOI

Church, J.E. \& Hodgson, W.C. 2002. The pharmacological activity of fish venoms. Toxicon, 40: 1083-1093. DOI

Egge, J.J.D. \& Simons, A.M. 2011. Evolution of venom delivery structures in madtom catfishes (Siluriformes: Ictaluridae). Biological Journal of the Linnean Society, 102: 115-129. D0I

Emmett, B. \& Cochran, P.A. 2010. The response of a piscivore (Micropterus salmoides) to a venomous prey species (Noturus gyrinus). Journal of Freshwater Ecology, 25: 475-479.

Fricke, R.; Eschmeyer, W.N. \& van der Laan, R. 2020. Eschmeyer's catalog of fishes: genera, species, references. Available: http://researcharchive. calacademy.org/research/ichthyology/catalog/fishcatmain.asp. Access: 15/11/2020.

Greven, H.; Flasbeck, T. \& Passia, D. 2006. Axillary glands in the armoured catfish Corydoras aeneus (Callichthyidae, Siluriformes). Verhandlungen der Gesellschaft für Ichthyologie, 5: 65-69.

Guazzelli, G.M. 2003. Relações filogenéticas do gênero Pimelodella Eigenmann and Eigenmann 1888 (Siluriformes, Pimelodidae). (Doctoral thesis) Universidade de São Paulo. São Paulo.

Günther, A. 1880. An introduction to the study offishes. London, Oxford University.
Gwee, M.C.E.; Gopalakrishnakone, P.; Yuen, R.; Khoo, H.E. \& Low, K.S.Y. 1994. A review of stonefish venoms and toxins. Pharmacology \& Therapeutics, 64(3): 509-528. DOI

Haddad, V. 2016. Injuries by Vertebrate Aquatic Animals: Phylum Chordata (Fish, Reptiles, and Mammals). In: Haddad, V. Medical emergencies caused by aquatic animals. Switzerland, Springer. p. 35-85. D0I

Haddad, V. \& Martins, I.A. 2006. Frequency and gravity of human envenomations caused by marine catfish (suborder Siluroidei): a clinical and epidemiological study. Toxicon, 47(8): 838-843. D0I

Hahn, S.T. \& O'Connor, J.M. 2000. An investigation of the biological activity of bullrout (Notesthes robusta) venom. Toxicon, 38(1): 79-89. D0I

Halstead, B.W. 1970. Poisonous and venomous marine animals of the world. Volume 3: Vertebrates. The Darwin Press, Princeton.

Halstead, B.W. 1978. Poisonous and venomous marine animals of the world. Princeton, The Darwin Press.

Halstead, B.W. 1988. Poisonous and venomous marine animals of the world. 2.ed. rev. Princeton, The Darwin Press.

Halstead, B.W. \& Smith, R.L. 1954. Presence of an axillary venom gland in the Oriental catfish Plotosus lineatus. Copeia, 1954(2): 153-154.

Halstead, B.W.; Kuninobu, L.S. \& Hebard, H.G. 1953. Catfish stings and the venom apparatus of the mexican catfish, Galeichthys felis (Linnaeus). Transactions of the American Microscopical Society, 72(4): 297-314.

Innes, W.T. \& Myers, G.S. 1950. The "Imitator catfish," which mimics a Corydoras. The Aquarium, 19: 222-223.

Jawad, L.A. 2018. Dangerous fishes of the eastern and southern Arabian Peninsula. Cham, Springer. DOI

Kiehl, E.; Rieger, C. \& Greven, H. 2006. Axillary gland secretions contribute to the stress-induced discharge of a bactericidal substance in Corydoras sterbai (Callichthyidae, Siluriformes). Verhandlungen der Gesellschaft für Ichthyologie, 5: 111-115.

Kubicek, K.M.; Britz, R. \& Conway, K.W. 2019. Ontogeny of the catfish pectoral-fin spine (Teleostei: Siluriformes). Journal of Morphology, 280(3): 339-359. DOI

Lundberg, J.G. \& McDade, L.A. 1986. On the South American catfish Brachyrhamdia imitator Myers (Siluriformes, Pimelodidae), with a phylogenetic evidence for a large intrafamilial lineage. Notulae Nature, 463: 1-24.

Magalhães, G.S.; Lopes-Ferreira, M.; Junqueira-de-Azevedo, I.L.M.; Spencer, P.J.; Araúujo, M.S.; Portaro, F.C.V.; Ma, L.; Valente, R.H.; Juliano, L.; Fox, J.W.; Ho, P.L. \& Moura-da-Silva, A.M. 2005. Natterins, a new class of proteins with kininogenase activity characterized from Thalassophryne nattereri fish venom. Biochimie, 87(8): 687-689. DOl

Nelson, J.S.; Grande, T.C. \& Wilson, M.V.H. 2016. Fishes of the world. 5.ed. New Jersey, Wiley.

Ota, R.R.; Message, H.J.; da Graça, W.J. \& Pavanelli, C.S. 2015. Neotropical Siluriformes as a model for insights on determining biodiversity of animal groups. PlosONE, 10(7): e0132913. DOI

Perrière, C. \& Goudey-Perrière, F. 2003. Poisonous catfishes: venom apparatus, acanthotoxins, crinotoxins and other skin secretions. In: Arratia, G.; Kapoor, B.G.; Chardon, M. \& Diogo, R. Catfishes. New Jersey, Science Publishers. v. 1, p. 291-314.

Reed, H.D. 1907. The poison glands of Noturus and Schilbeodes. American Naturalist, 41: 553-566.

Remington, C.L. 1963. Historical backgrounds of mimicry. In: International Congress of Zoology, 16º. Proceedings. Washington, ICZ, 1964. p. $145-149$

Sabaj, M.H. 2016. Standard symbolic codes for institutional resource collections in herpetology and ichthyology: an Online Reference. Available: https:// asih.org/sites/default/files/documents/symbolic codes for collections v6.5 2016.pdf. Access: 16/08/2016. 
Sands, D.D. 1985. Brachyrhamdia, cryptic or mimetic catfishes from South America: Zoomimesis, camouflage or mimicry. In: Sands, D. (Ed.). Catfishes of the World. Self published, Scotland. p. 51-58.

Schultz, L.P. 1944. The catfishes of Venezuela, with descriptions of thirtyeight new forms. Proceedings of the United States National Museum, 94: 173-338, pls. 1-14.

Silva, G.C.; Sabino, J.; Alho, C.J.R.; Nunes, V.L.B. \& Haddad, V. 2010. Injuries and envenoming by aquatic animals in fishermen of Coxim and Corumbá municipalities, State of Mato Grosso do Sul, Brazil: identification of the causative agents, clinical aspects and first aid measures. Revista da Sociedade Brasileira de Medicina Tropical, 43(5): 486-490. DOI

Silva, G.S.C.; Roxo, F.F.; Melo, B.F.; Ochoa, L.E.; Bockmann, F.A.; Sabaj, M.H; Jerep, F.C.; Foresti, F.; Benine, R.C. \& Oliveira, C. 2021. Evolutionary history of Heptapteridae catfishes using ultraconserved elements (Teleostei, Siluriformes). Zoologica Scripta, 2021, 00: 1-12. D0I

Slobodian, V. 2013. Taxonomia, Sistemática e Biogeografia de Brachyrhamdia Myers, 1927 (Siluriformes: Heptapteridae), com uma investigação sobre seu mimetismo com outros Siluriformes. (Masters dissertation) Universidade de São Paulo. Ribeirão Preto.

Slobodian, V. \& Bockmann, F.A. 2013. A new Brachyrhamdia (Siluriformes: Heptapteridae) from Rio Japurá basin, Brazil, with comments on its phylogenetic affinities, biogeography and mimicry in the genus. Zootaxa, 3717(1): 1-22. DOI

Smith, W.L. \& Wheeler, W.C. 2006. Venom evolution widespread in fishes: a phylogenetic road map for the bioprospecting of piscine venoms. Journal of Heredity, 97(3): 206-17. D0I

Smith, W.L.; Stern, J.H.; Girard, M.G. \& Davis, M.P. 2016. Evolution of Venomous Cartilaginous and Ray-Finned Fishes. Integrative and Comparative Biology, 56(5): 950-961. DOI
Taylor, W.R. \& Van Dyke, G.C. 1985. Revised procedures for staining and clearing small fishes and other vertebrates for bone and cartilage study. Cybium, 9(2): 107-119.

Vanscoy, T.; Lundberg, J.G. \& Luckenbill, K.R. 2015. Bony ornamentation of the catfish pectoral-fin spine: comparative and developmental anatomy, with an example of fin-spine diversity using the Tribe Brachyplatystomini (Siluriformes, Pimelodidae). Proceedings of the Academy of Natural Sciences of Philadelphia, 164: 177-212.

Vernick, S.H. \& Chapman, G.B. 1968. Ultrastructure of axillary glands of the toadfish Opsanus tau. Chesapeake Science, 9(3): 182-197.

Whitear, M.; Zaccone, G.; Fasulo, S. \& Licata, A. 1991. Fine structure of the axillary gland of the brown bullhead (Ictalurus nebulosus). Journal of Zoology, 224: 669-676.

Wright, J.J. 2009. Diversity, phylogenetic distribution, and origins of venomous catfishes. BMC Evolutionary Biology, 9(1): 282. DOI

Wright, J.J. 2012. The evolutionary ecology of venomous catfishes, with a focus on members of the north American family Ictaluridae (Teleostei: Siluriformes). (Doctoral thesis) Michigan University, Ann Arbor.

Wright, J.J. 2015. Evolutionary History of Venom Glands in the Siluriformes. In: Gopalakrishnakone, P. \& Malhotra, A. (Eds.). Evolution of Venomous Animals and Their Toxins. Dordrecht, Springer. p. 1-19. D0I

Zaccone, G.; Kapoor, B.G.; Fasulo, S. \& Ainis, L. 2001. Structural. histochemical and functional aspects of the epidermis of fishes. Advances in Marine Biology, 40: 255-347.

Zaccone, G.; Tagliaferro, G.; Fasulo, S.; Contini, A.; Ainis, L. \& Licata, A. 1990. Serotonin-like immunoreactivity in the epidermal club cells of teleost fishes. Histochemistry, 93(4): 355-357. 